\title{
Petrological Properties of Flat Stones from the Obongsan Mountain Quarry Used for Flooring in Ondol
}

\author{
Jae Hwan Kim', Min Su Han,* \\ ${ }^{1}$ Division of Natural Science, National Research Institute of Cultural Heritage, Daejeon 35204, Korea \\ ${ }^{2}$ Department of Heritage Conservation and Restoration, Graduate School of Cultural Heritage, Korea National University of \\ Cultural Heritage, Buyeo 33115, Korea
}

\author{
Received July 31, 2021 \\ Revised August 10, 2021 \\ Accepted August 13, 2021 \\ *Corresponding author \\ E-mail: dormer@nuch.ac.kr \\ Phone: +82-41-830-7381 \\ Journal of Conservation Science \\ 2021;37(4):380-390 \\ https://doi.org/10.12654/JCS.2021. \\ 37.4.07 \\ pISSN: 1225-5459, eISSN: 2287-9781 \\ (C) The Korean Society of \\ Conservation Science for Cultural \\ Heritage \\ This is an Open-Access article distributed \\ under the terms of the Creative \\ Commons Attribution Non-Commercial \\ License (http://creativecommons.org/ \\ licenses/by-nc/3.0) which permits \\ unrestricted non-commercial use, \\ distribution, and reproduction in any \\ medium, provided the original work is \\ properly cited.
}

\begin{abstract}
The purpose of this study is to scientifically analyze the rocks of the Obongsan Mountain in Boseong, Jeollanam-do, which contains the largest extant quarry of Gudlejang (flat stone for heating) in Korea, and to scientifically determine the petrological characteristics of the area and the reasons for its use as a quarry. The rocks in the quarry are composed of light-green lapilli tuff, containing various types of lithic fragments and crystalline fragments in a vitreous matrix consisting of the fine feldspar crystals. The main constituent minerals were identified as quartz, plagioclase, mica, chlorite and opaque minerals. When the major element compositions were plotted on a $\mathrm{Na}_{2} \mathrm{O}+\mathrm{K}_{2} \mathrm{O}$ versus $\mathrm{SiO}_{2}$ diagram, all samples were situated in the same compositional area as rhyolite. In addition, the result of magnetic susceptibility measurement also showed a similar range of values, of $1.30 \sim 4.85\left(\times 10^{-3}\right.$ SI), indicating that samples were fractionated from the same magma. Both rock types showed similar apparent specific gravity values of $2.32 \sim 2.60$. In particular, plate-shaped joints are well developed in the Obongsan Mountain area, and many areas exhibit talus terrain. In conclusion, the rocks of this area is interpreted to used for a site of Gudlejang quarrying, because the rocks were easily obtainable due to the terrain characteristics, and their petrological properties made them suitable for use as Gudlejang stone.
\end{abstract}

Key Words Ondol, Gudlejang, Talus, Obongsan, Lapilli tuff

\section{INTRODUCTION}

Ondol is a traditional heating system used in traditional Korean architecture and is well known as a very practical and scientific heating method. It is thought to have been used since prehistoric times, and it appears in the mural paintings of the Tomb No.3 Anak Tomb in Hwanghae-do, from around the $4^{\text {th }}$ century. It is generally known that houses were heated using this method during the Goryeo Dynasty, and its use spread nationwide from the Joseon Dynasty (Cha, 2017).

The traditional ondol system involves the heating of a Gudlejang (flat stone) by a fire burning beneath the floor. These Gudeul structures are known to have various historical and regional designs, and one of the key elements of these structures is the stone used as the Gudlejang. In the literature, 'Gudeul' is used as a shortened word for 'roasted stone', and this argument can be confirmed by calling it 'gudol' in a tradition private house (Kim, 1992).

Gudlejang (also called Bangjang or Ondolseok) stones, used in the traditional design and construction of Gudeul structures, store the thermal energy created through combustion gases. Flat granite or muscovite stones are mainly used (Jung, 2006), while the stones used as Gudlejang in the Standard Specification for the Repair of Cultural Heritage (Cultural Heritage Administration, 2005) are granite and slate. In general, Gudlejang stones should be easily split into 
thin plates. From a petrological point of view, metamorphic rocks such as slate with thin splitting properties (exfoliation) or schist with distinct schistosity are advantageous. Of course, the options of suitable stones are very diverse because both igneous rocks, such as granite, and sedimentary rocks with well-developed bedding can be used.

Obongsan Quarry in Boseong, Jeollanam-do is the largest extant Gudlejang quarry, and its academic and historical value has been recognized in through previous studies. Therefore, this study aimed to verify the scientific validity of the Obongsan Quarry as a souce of Gudlejang by analyzing the physical, petrological, and geochemical characteristics of the rocks to collected here.

\section{MATERIALS AND METHODS}

\subsection{Location}

\subsubsection{Geological summary}

Obongsan Mountain is located at the southern tip of the Korean Peninsula and borders the South Sea. It is located at $34^{\circ} 40^{\prime} \sim 34^{\circ} 50^{\prime} \mathrm{N}$ latitude and $127^{\circ} 00^{\prime} \sim 127^{\circ} 15^{\prime} \mathrm{E}$ longitude. The Obongsan Mountain (382 $\mathrm{m}$ ) area is composed of volcanic rocks and the terrain has a cone-shape with a steeply sloping terrain. Some areas form a talus terrain, while the others have a gentle slope and form a low mountainous terrain. Talus refers to a semi-conical terrain in which rock fragments split by external factors are rolled and deposited by gravity (Lee et al., 2009). The rocks distributed in the Obongsan Mountain comprise the Obongsan Brecciated Tuff, Dochon-ri Rhyolite and Gaeksan-ri Porphyrite from the Cretaceous Period, as well as a large feldspar breccia, which is exposed on the lower slopes of Obongsan Mountain. The Gudlejang quarry is located in Obongsan Brecciated Tuff (Hwang and Jong, 1968) (Figure 1).

The volcanic activity that led to the deposited of Obongsan Brecciated Tuff began after the eruption of the Gaeksan-ri Porphyrite and continued until the end of the Dochon-ri Rhyolite eruption. The Obongsan Brecciated Tuff is the most widely distributed member of the Gyeongsang System. It starts at Deukryang-ri and extends to the peak of Wongosang in the shape of a crescent moom, forming the Deukryang-myeon -Hoecheon-myeon system. The strike of this deposit is not always clear, but it is generally inclined from $10^{\circ}$ to $45^{\circ}$ toward the northwest; overrall, it forms a gentle slope of less than $30^{\circ}$. In particular, sheet jointing is well developed within this rock type, and the plate-shaped fragments of this rock are collected and used as Gudlejang in Ondol systems, due to their tendency to split easily along the exfoliation surface parallel to the mountain slope (Hwang and Jong, 1968).

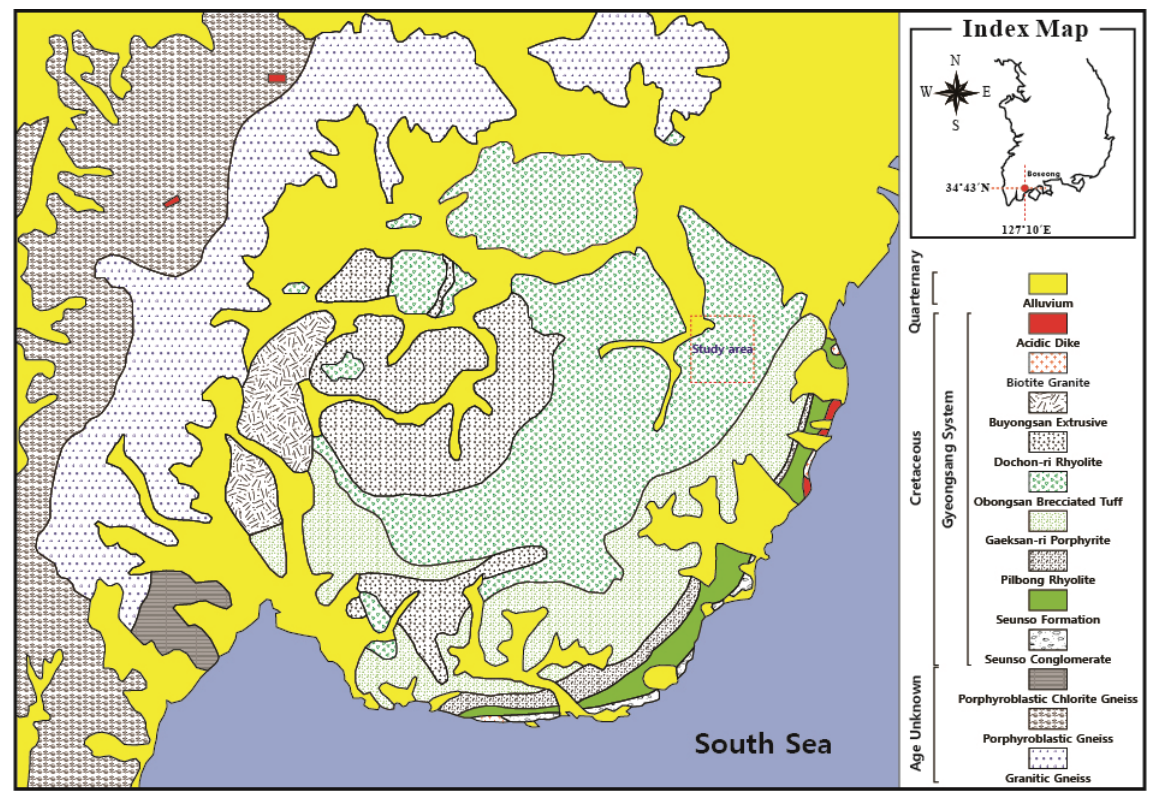

Figure 1. Geologic map of the study area (modified Hwang and Jong, 1968). 


\subsubsection{Study area}

The research and sampling site is located in the Obongsan Mountain area, which can be divided into the administrative districts of Mount Cheongbang and Mount Obong. The target area (indicated in Figure 1) was limited to the Obongsan Mountain area and was centered on the Haepyeong-ri reservoir.

The geographical features and regional rock distribution data of the Obongsan Mountain study area were reviewed.
For comparison, stone samples were collected from four sites specially designated by the International Society of Ondol (Kim, 2021) (Gudlejang quarry sites A to D) and one sample was obtained from surrounding outcrop (Site E, start of the Yongchu Valley mountaineering trail) (Table 1, Figure 2). In addition, the surrounding rock formations that could not be accessed during geological surveys were examined from photographs taken at a distance (Figure 2). The remains of
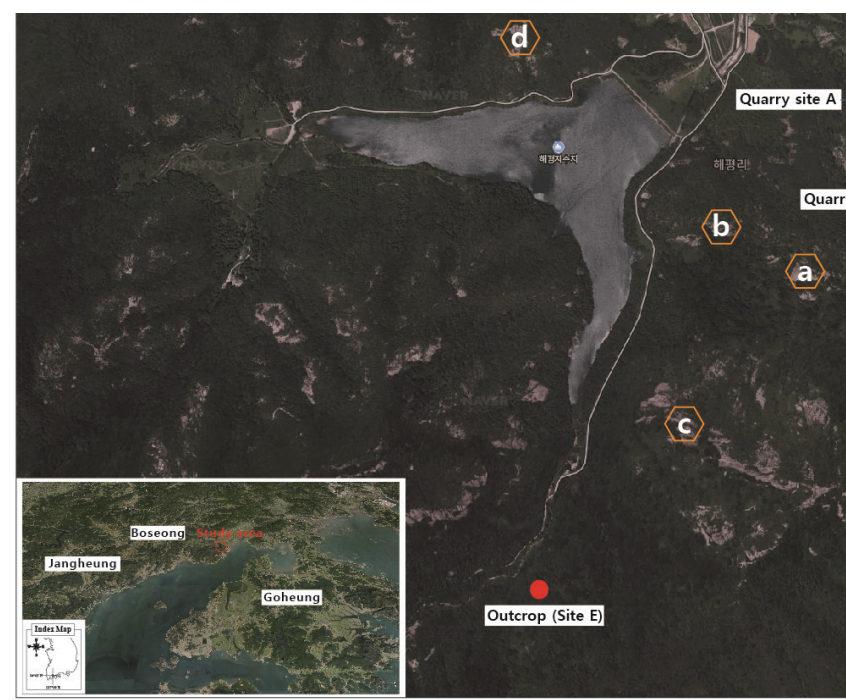

Quarry site A
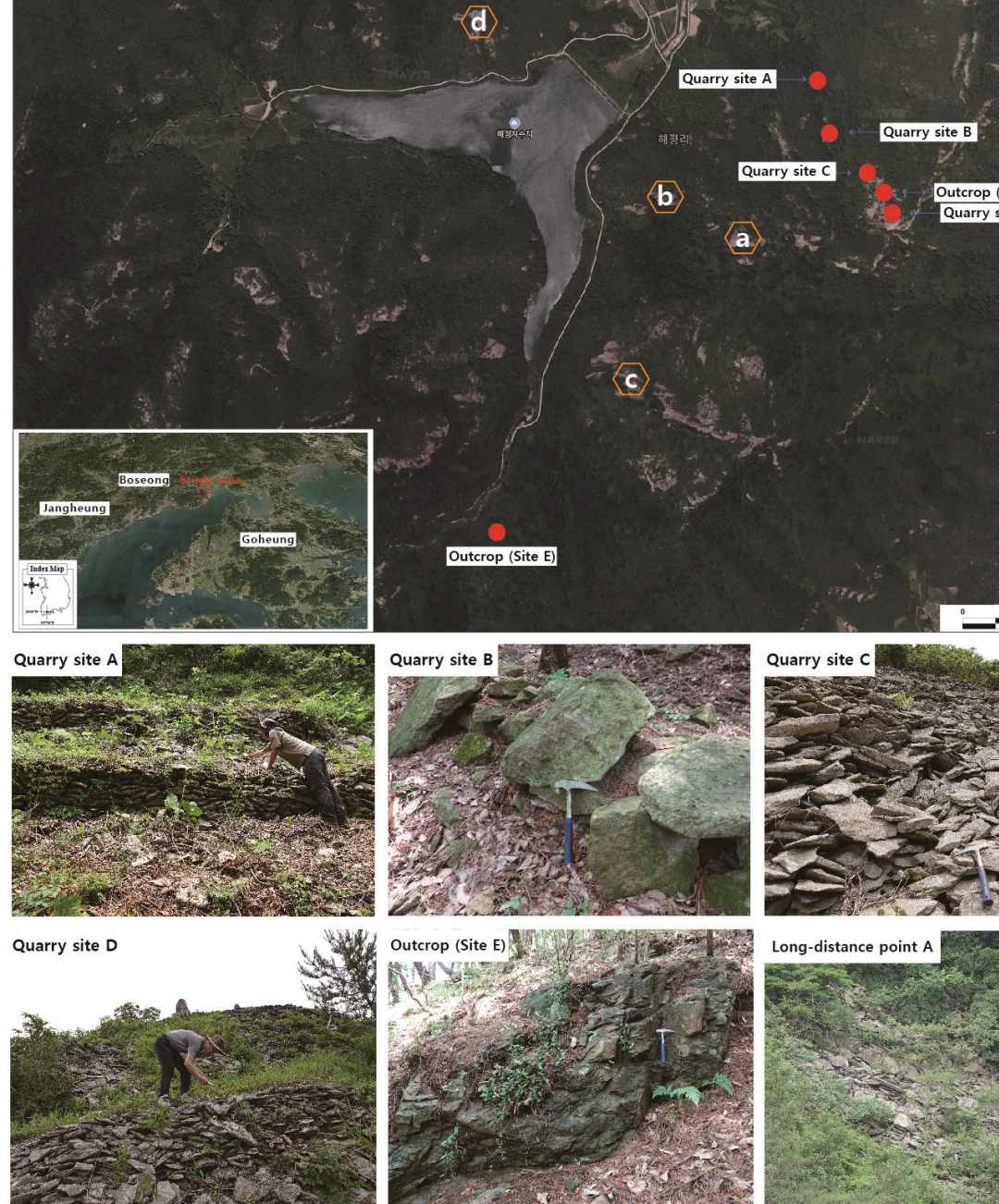

Quarry site C
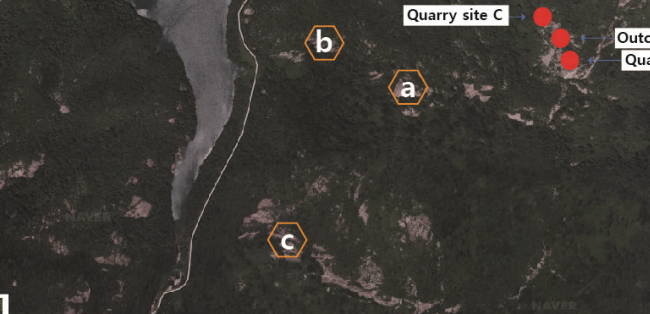

c)
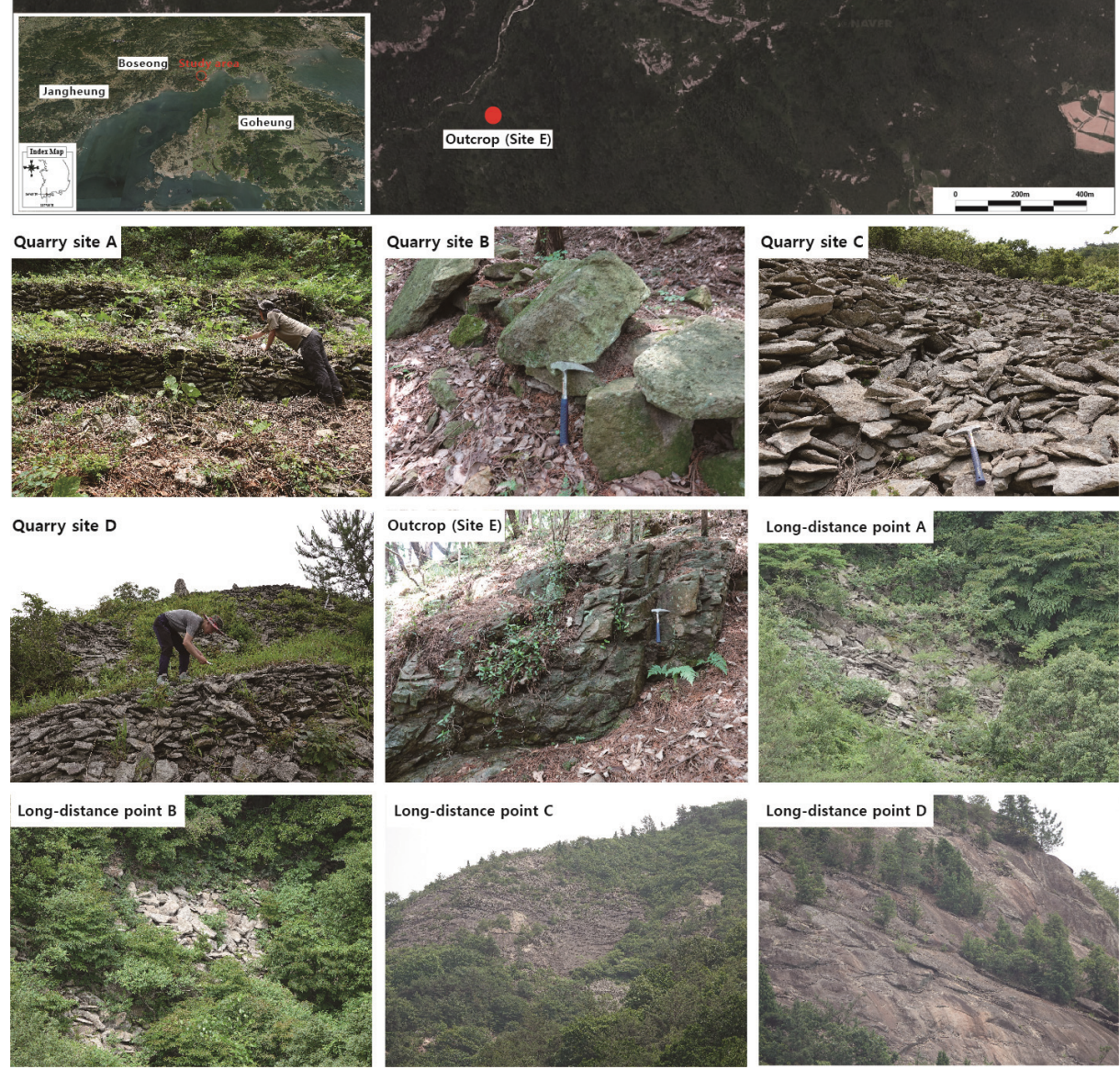

Figure 2. Location of geological survey sites and foreground of Obongsan Mountain, Boseong. 
Table 1. Locations of sampling points

\begin{tabular}{ccccc}
\hline Study sites & \multicolumn{3}{c}{ Latitude / Longitude } & Altitude (m) \\
\hline Quarry site A & $\mathrm{N}: 34^{\circ} 44^{\prime}$ & $01.2^{\prime \prime}$, E: $127^{\circ} 11^{\prime}$ & $44.5^{\prime \prime}$ & 94 \\
Quarry site B & $\mathrm{N}: 34^{\circ} 43^{\prime}$ & $56.7^{\prime \prime}$, E: $127^{\circ} 11^{\prime}$ & $48.0^{\prime \prime}$ & 156 \\
Quarry site C & $\mathrm{N}: 34^{\circ} 43^{\prime}$ & $53.4^{\prime \prime}$, E: $127^{\circ} 11^{\prime}$ & $51.3^{\prime \prime}$ & 218 \\
Quarry site D & $\mathrm{N}: 34^{\circ} 43^{\prime}$ & $49.2^{\prime \prime}$, E: $127^{\circ} 11^{\prime}$ & $54.0^{\prime \prime}$ & 314 \\
Outcrop (site E) & $\mathrm{N}: 34^{\circ} 43^{\prime}$ & $21.3^{\prime \prime}$, E: $127^{\circ} 11^{\prime}$ & $09.3^{\prime \prime}$ & 92 \\
\hline
\end{tabular}

a stepped stone wall can be seen in the quarry in site A. Although quarried rock is spread over the top of the stone wall, it is currently covered with trees, making it difficult to access. Site B is located at the bottom of the Obongsan Mountain, and contains many flat stones that can be used as Gudlejang. Site $\mathrm{C}$ is located in a quarry on the side of Obongsan Mountain, where the terrain is very steep, and many flat stones have rolled down from higher up, covering the slope. Site D is a large and well-preserved quarry site located at the top of Obongsan Mountain. Flat stones are mainly distributed on steep slopes of approximately $60^{\circ}$ or more, and several stone towers (formed by piling up the flat stones) have been erected at the top. In addition, photographs of the inaccessible outcrops (Long-distance points a and $b$ of hexagonal, in Figure 2) show that bedding is well developed in the bedrock, and the terrain on which flat stones have rolled down slopes can be observed everywhere.

\subsection{Methods}

During the field survey, the location of each survey point was measured using a GPS (GPSmap 60CSx, Garmin, USA), and the homogeneity of the rocks was identified by visual observation. Magnetic susceptibility analysis of the distributed rocks was conducted using a SM-30 meter, manufactured by ZH instruments in the Czech Republic, and a sensitivity of $10^{-3} \mathrm{SI}$ Unit. Samples were collected at quarry sites $(\mathrm{A} \sim \mathrm{D})$ and outcrop site $\mathrm{E}$ to identify the mineral composition of the rocks, the formation of altered minerals due to weathering, and the major element contents. The collected samples were cut into cubes $(5 \times 5 \times 5 \mathrm{~cm})$ and completely dried at $100 \pm 5^{\circ} \mathrm{C}$ for more than $24 \mathrm{~h}$. The dried samples were weighed $\left(\mathrm{W}_{1}\right)$, and immersed in distilled water for $24 \mathrm{~h}$. The water-soaked samples were weighted in air $\left(\mathrm{W}_{2}\right)$ and in water $\left(\mathrm{W}_{3}\right)$. Some fragments of the samples were made as thin sections and also as powders. The equipments used were polarizing microscope (Eclipse LV100n pol, Nikon, Japan), X-ray diffractometer (Miniflex, Rigaku, Japan) and X-ray fluorescence spectrometer (WD-XRF, PW2404, Philips, Netherland). In addition, the absorption rate, apparent porosity, and apparent gravity were measured and analyzed using precision electronic scales (GR-200, AND, Japan) and a specific gravity determination kit (AD-1653, AND, Japan) to compare the physical properties related to the pores of rocks.

\section{RESULTS}

\subsection{Geological properties}

A regional geological survey was conducted to determine the petrographic characteristics of the constituent rocks distributed in Obongsan Mountain area, Boseong, which is known as the largest Gudlejang quarry in Korea. Samples A-1 to D-2, obtained from the Gudlejang quarry, were all composed of light-green lapilli tuff, containing lithic fragments of various sizes. However, the samples obtained at site E (Sample E-1 and E-2), at the start of the mountaineering trail in Yongchu Valley, were grayish-white and were identified as rhyolitic tuff. By examining thin sections and rock cross-sections with a polarized microscope, the lapilli tuff was found to contain various types of lithic fragments and crystalline fragments in a vitreous matrix, with subangular to angular breccia clasts. The matrix consisted of fine feldspar crystals, and the feldspar and mafic minerals were altered to chlorite and other alteration minerals. The sample C-1 was identified as rhyolitic tuff and comprised crystalline fragments in a matrix, with small amounts of lithic fragments. The main constituent minerals of the lapilli tuff and rhyolitic tuff were quartz, plagioclase, mica, chlorite, and opaque minerals (Figure 3). In some samples, the constituent minerals formed fine particles while others exhibited sever 

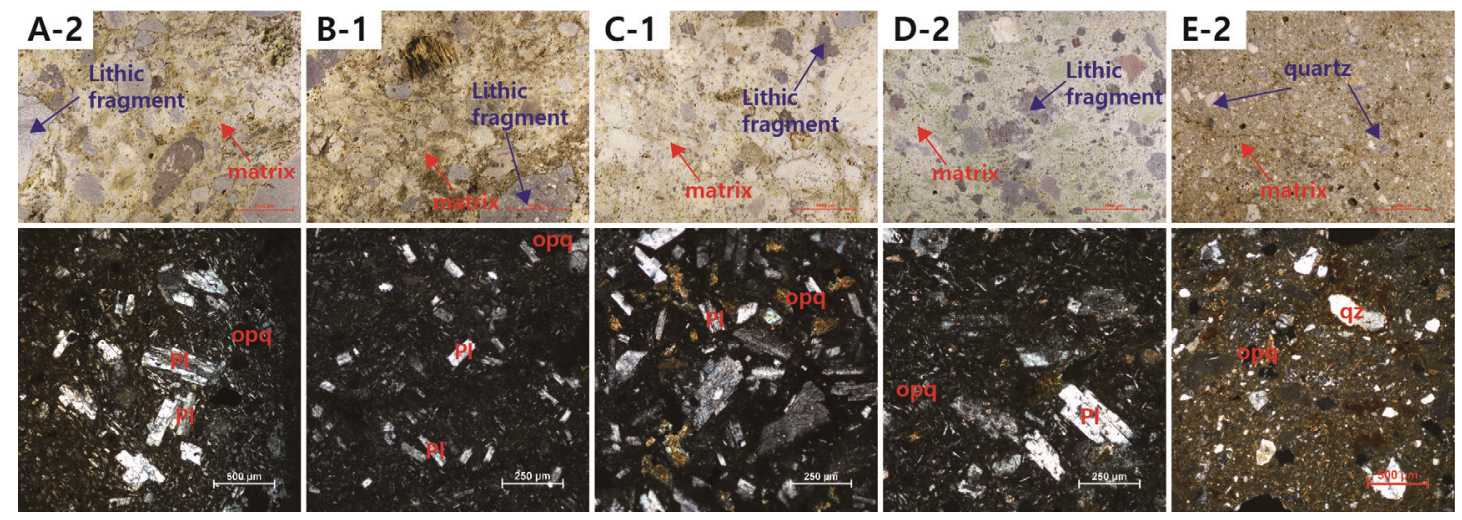

Figure 3. Photographs of slabs and thin sections of the constituent rocks of Obongsan Mountain, under a polarized-light microscope analysis. Samples A-2 to E-2 were obtained from the locations indicated in Figure 2 (qz; quartz, pl; plagioclase, opq; opaque mineral).

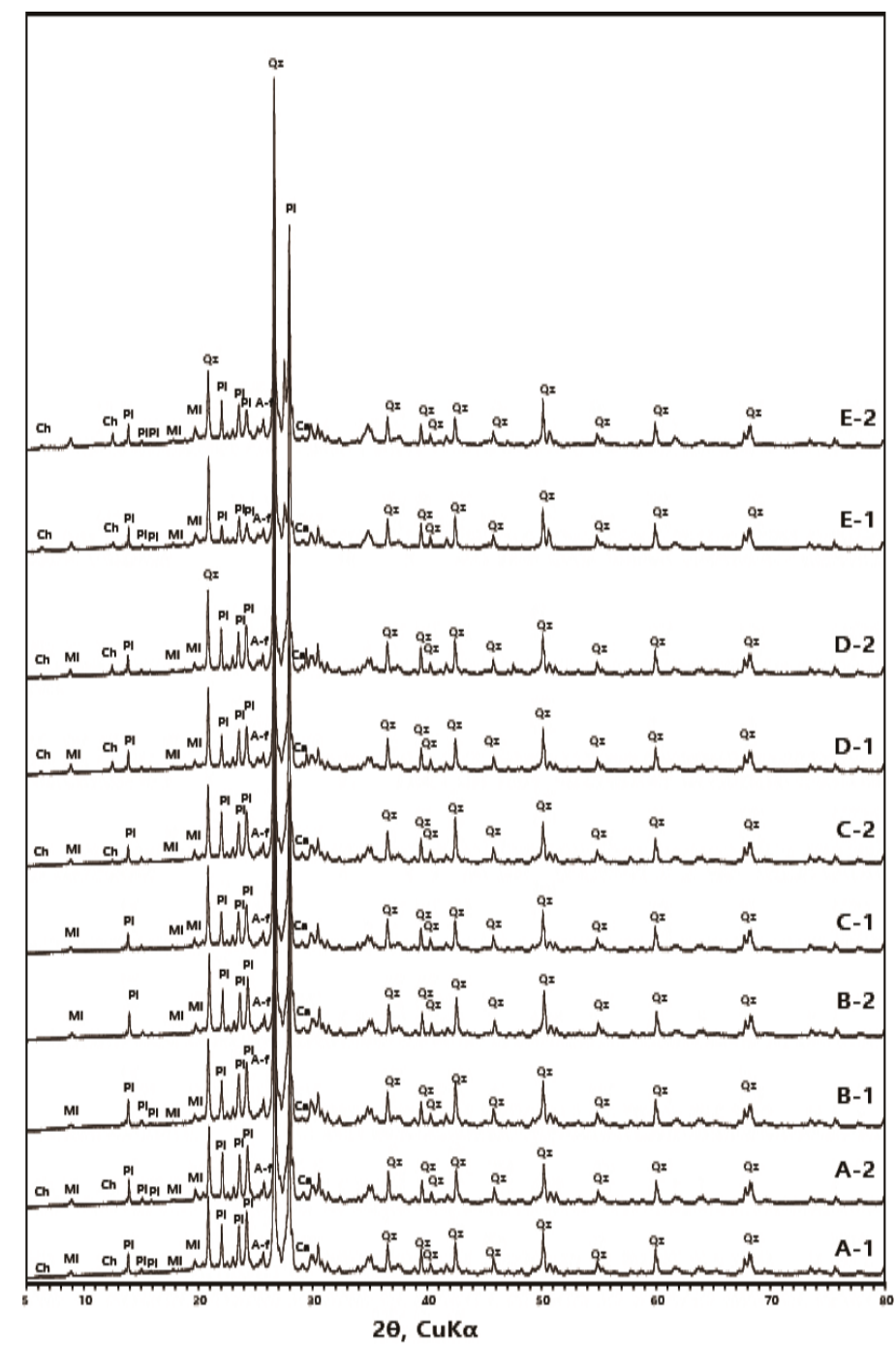

Figure 4. X-ray diffraction analysis of the constituent rocks of Obongsan Mountain. Samples A-1 to E-2 were obtained from the locations indicated in Figure 2 (Qz; quartz, Pl; plagioclase, Ca; calcite, Mi; mica, A-f; alkali-feldspar, Ch; chlorite). 
alteration due to weathering. In such cases, identification of the minerals was very challenging and additional crystal structure analysis was performed.

The XRD analysis revealed that the main constituent minerals were quartz, plagioclase, alkali feldspar, mica, chlorite, and calcite. Most of the feldspars were plagioclase, with limited alkali feldspars. Although chlorite was not detected in some samples, the mineral composition of the lapilli tuff and rhyolitic tuff, determined through X-ray diffraction analysis of 10 samples, was found to be similar (Figure 4).

\subsection{Magnetic susceptibility}

The magnetic susceptibility of the stones in the Gudlejang quarry (Sites A to D) were measured and compared with those obtained from the surrounding outcrop (Site E) at the Obongsan Mountain site in Boseong. The magnetic susceptibility method measures the degree to which a rock can be magnetized, relative to an external magnetic field. This method has been used to classify rock samples that are difficult to identify through optical methods, because the magnetic susceptibility value varies with the amount of strongly magnetic minerals. This magnetic susceptibility method is widely used in geological petrogenesis research, as well as for estimating the origin of culturally significant stone objects by identifying the homogeneity of rocks (Jwa et al., 2006; Uchida et al., 2007; Kim and Jwa, 2010).

The magnetic susceptibility was measured 10 times at each sampling point. The magnetic susceptibility values in sites A to D ranged from 1.30 to $4.85\left(\times 10^{-3} \mathrm{SI}\right)$, with high-altitude sites (D and $\mathrm{D}^{\prime}$ ) showing relatively higher values. However, in terms of petrogenesis, the samples likely fractionated from the same magma. At site E, some distance from the quarry, the magnetic susceptibility values were 0.12 to $0.18\left(\times 10^{-3} \mathrm{SI}\right)$, lower than that of the stones in the Gudlejang quarry. This indicates that the two types of rocks are petrogenetically different (Figure 5).

\subsection{Geochemical properties}

Table 2 shows the results of major element analysis and CIPW norm values for the lapilli tuff and rhyolitic tuff samples collected from the Gudlejang quarry (Samples A-1 to D-2) and surrounding rocks (E-1 and E-2) at the Obongsan Mountain site in Boseong.

Major element analysis of the samples revealed the following contents: $\mathrm{SiO}_{2} 69.6 \sim 74.4$ wt. $\%, \mathrm{Al}_{2} \mathrm{O}_{3} 13.8 \sim 15.7$

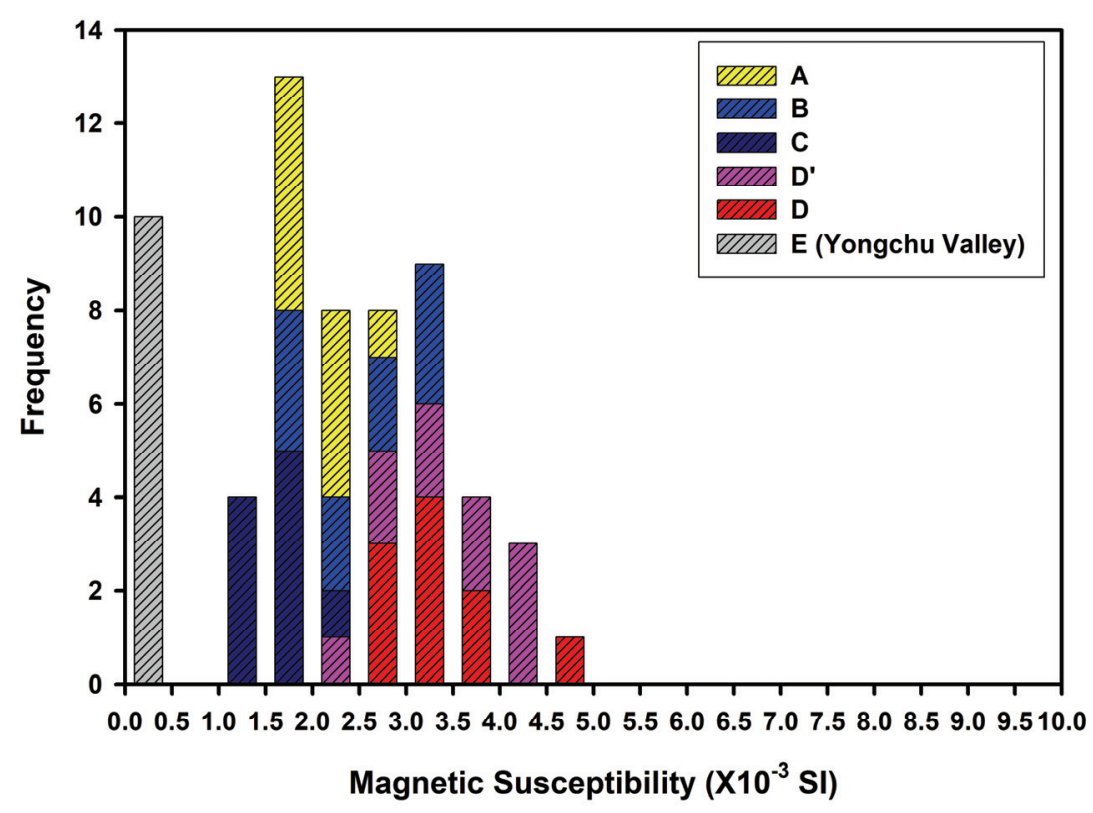

Figure 5. Histogram of magnetic susceptibility of the constituent rocks of Obongsan Mountain. Sites A to E were indentical from the locations indicated in Figure 2. 
Table 2. Major element contents (wt.\%) and CIPW norms for the lapilli tuff and rhyolitic tuff samples (LT; Lapilli Tuff, RT; Rhyolitic Tuff). Samples A-1 to E-2 were obtained from the locations indicated in Figure 2

\begin{tabular}{|c|c|c|c|c|c|c|c|c|c|c|}
\hline Sample & A-1 & A-2 & B-1 & B-2 & C-1 & $\mathrm{C}-2$ & D-1 & D-2 & E-1 & E-2 \\
\hline Rock type & $\mathbf{L T}$ & $\mathbf{L T}$ & LT & LT & $\mathbf{L T}$ & LT & $\mathbf{L T}$ & LT & RT & RT \\
\hline Symbol & 0 & o & 口 & 口 & $\triangle$ & $\triangle$ & $\diamond$ & $\diamond$ & • & • \\
\hline $\mathrm{SiO}_{2}$ & 72.13 & 71.69 & 71.50 & 73.26 & 74.14 & 74.40 & 72.76 & 71.39 & 71.95 & 69.64 \\
\hline $\mathrm{TiO}_{2}$ & 0.21 & 0.21 & 0.21 & 0.19 & 0.19 & 0.18 & 0.27 & 0.26 & 0.32 & 0.36 \\
\hline $\mathrm{Al}_{2} \mathrm{O}_{3}$ & 15.02 & 14.74 & 14.73 & 14.45 & 13.93 & 14.19 & 13.76 & 14.15 & 14.59 & 15.7 \\
\hline $\mathrm{Fe}_{2} \mathrm{O}_{3}$ & 2.66 & 2.88 & 2.69 & 2.47 & 2.12 & 1.98 & 2.93 & 2.56 & 3.2 & 3.45 \\
\hline MnO & 0.11 & 0.12 & 0.12 & 0.07 & 0.08 & 0.05 & 0.08 & 0.07 & 0.04 & 0.06 \\
\hline MgO & 0.35 & 0.23 & 0.32 & 0.28 & 0.22 & 0.23 & 0.52 & 0.41 & 0.54 & 0.5 \\
\hline $\mathrm{CaO}$ & 0.26 & 0.31 & 0.24 & 0.23 & 0.27 & 0.27 & 0.96 & 1.6 & 0.15 & 0.28 \\
\hline $\mathrm{Na}_{2} \mathrm{O}$ & 3.29 & 3.73 & 3.58 & 3.35 & 3.42 & 3.5 & 3.17 & 3.47 & 1.55 & 2.29 \\
\hline $\mathbf{K}_{2} \mathbf{O}$ & 4.04 & 4.64 & 4.98 & 4.29 & 4.32 & 4.04 & 3.92 & 4.11 & 4.87 & 5.5 \\
\hline $\mathbf{P}_{2} \mathbf{O}_{5}$ & 0.02 & 0.04 & 0.04 & 0.04 & 0.05 & 0.04 & 0.06 & 0.06 & 0.02 & 0.09 \\
\hline L.O.I. & 1.91 & 1.42 & 1.57 & 1.36 & 1.25 & 1.12 & 1.58 & 1.89 & 2.76 & 2.12 \\
\hline \multicolumn{11}{|l|}{ CIPW norm } \\
\hline Quartz & 36.51 & 31.34 & 30.74 & 36.56 & 36.95 & 37.77 & 36.66 & 31.61 & 43.23 & 34.18 \\
\hline Plagioclase & 29.00 & 32.84 & 31.22 & 29.23 & 29.95 & 30.69 & 31.19 & 36.91 & 13.73 & 20.18 \\
\hline Orthoclase & 23.87 & 27.42 & 29.43 & 25.35 & 25.53 & 23.87 & 23.17 & 24.29 & 28.78 & 32.50 \\
\hline Corundum & 4.81 & 3.11 & 3.11 & 3.97 & 3.26 & 3.66 & 2.70 & 1.23 & 6.54 & 5.69 \\
\hline Hypersthene & 0.87 & 0.57 & 0.80 & 0.70 & 0.55 & 0.57 & 1.30 & 1.02 & 1.35 & 1.25 \\
\hline Rutile & 0.09 & 0.07 & 0.07 & 0.11 & 0.10 & 0.12 & 0.18 & 0.18 & 0.27 & 0.29 \\
\hline Ilmenite & 0.24 & 0.26 & 0.26 & 0.15 & 0.17 & 0.11 & 0.17 & 0.15 & 0.09 & 0.13 \\
\hline Hematite & 2.66 & 2.88 & 2.69 & 2.47 & 2.12 & 1.98 & 2.93 & 2.56 & 3.20 & 3.45 \\
\hline Apatite & 0.05 & 0.09 & 0.09 & 0.09 & 0.12 & 0.09 & 0.14 & 0.14 & 0.05 & 0.21 \\
\hline
\end{tabular}

wt. $\% \mathrm{Fe}_{2} \mathrm{O}_{3} 2.0 \sim 3.5$ wt. $\%, \mathrm{TiO}_{2} 0.18 \sim 0.36$ wt. $\%, \mathrm{MnO}$ $0.04 \sim 0.12$ wt. $\%, \mathrm{CaO} 0.15 \sim 1.60$ wt. $\%, \mathrm{MgO} 0.22 \sim$ 0.54 wt.\%, $\mathrm{Na}_{2} \mathrm{O} 1.55 \sim 3.73$ wt.\%, and $\mathrm{K}_{2} \mathrm{O}$ has a value of $3.92 \sim 5.50$ wt.\% (Table 1). Both the lapilli tuff and rhyolitic tuff samples were situated in the sub-alkaline rhyolite region of the TAS $\left(\mathrm{Na}_{2} \mathrm{O}+\mathrm{K}_{2} \mathrm{O}\right.$ versus $\left.\mathrm{SiO}_{2}\right)$ diagram, based on the analysis of the major elements (Figure 6). The samples were also classified as part of the non-alkali group, and when plotted in the AFM variation diagram, $\mathrm{MgO}$ and $\mathrm{FeO}$ gradually decrease as the fractionation proceeds, showing the typical trend of the calc-alkali rock type, moving toward $\mathrm{Na}_{2} \mathrm{O}+\mathrm{K}_{2} \mathrm{O}$ (Figure 7).

The lapilli tuff samples obtained from sites A to D in the
Gudlejang quarry exhibited similar major element concentrations, and but showed no clear trend with changing altitude. However, with increasing $\mathrm{SiO}_{2}$ content in the Harker variation diagram, the $\mathrm{Al}_{2} \mathrm{O}_{3}, \mathrm{Fe}_{2} \mathrm{O}_{3}, \mathrm{TiO}_{2}, \mathrm{MnO}$, and $\mathrm{MgO}$ contents of the samples are somewhat dispersed, but generally decrease, while the $\mathrm{CaO}, \mathrm{K}_{2} \mathrm{O}, \mathrm{Na}_{2} \mathrm{O}$, and $\mathrm{P}_{2} \mathrm{O}_{5}$ contents are almost constant. In particular, samples taken from site $\mathrm{D}$, at high altitude, had relatively high $\mathrm{CaO}$ contents. Sample E-1 and E-2, obtained at some distance from the Gudlejang quarry, exhibited relatively high $\mathrm{Fe}_{2} \mathrm{O}_{3}$ contents, while the $\mathrm{Na}_{2} \mathrm{O}$ content was lower than that of the lapilli tuff (Figure 8). 


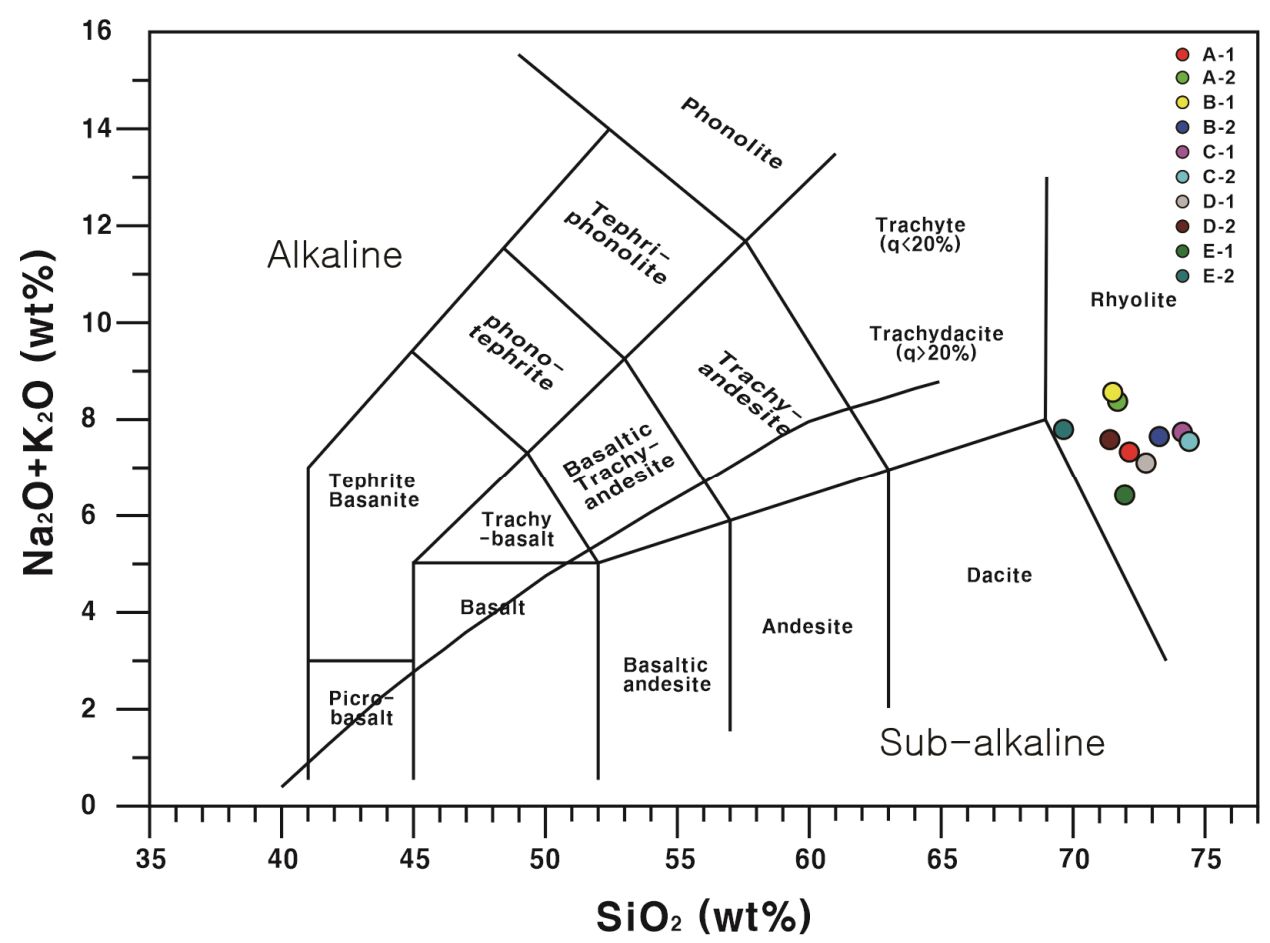

Figure 6. Plot of total alkali versus $\mathrm{SiO}_{2}$ (wt.\%) content of the lapilli tuff and the rhyolitic tuff samples. Samples A-1 to E-2 were obtained from the locations indicated in Figure 2.

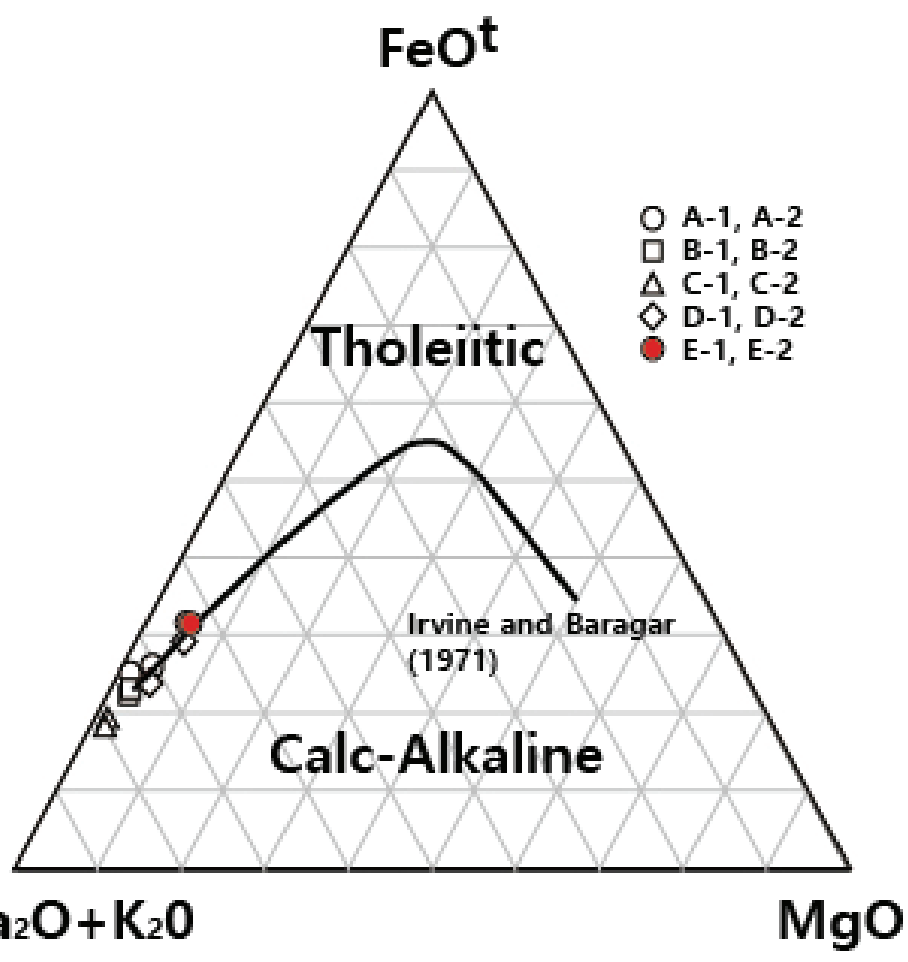

Figure 7. AFM diagram for samples of lapilli tuff and rhyolitic tuff. Samples A-1 to E-2 were obtained from the locations indicated in Figure 2. 

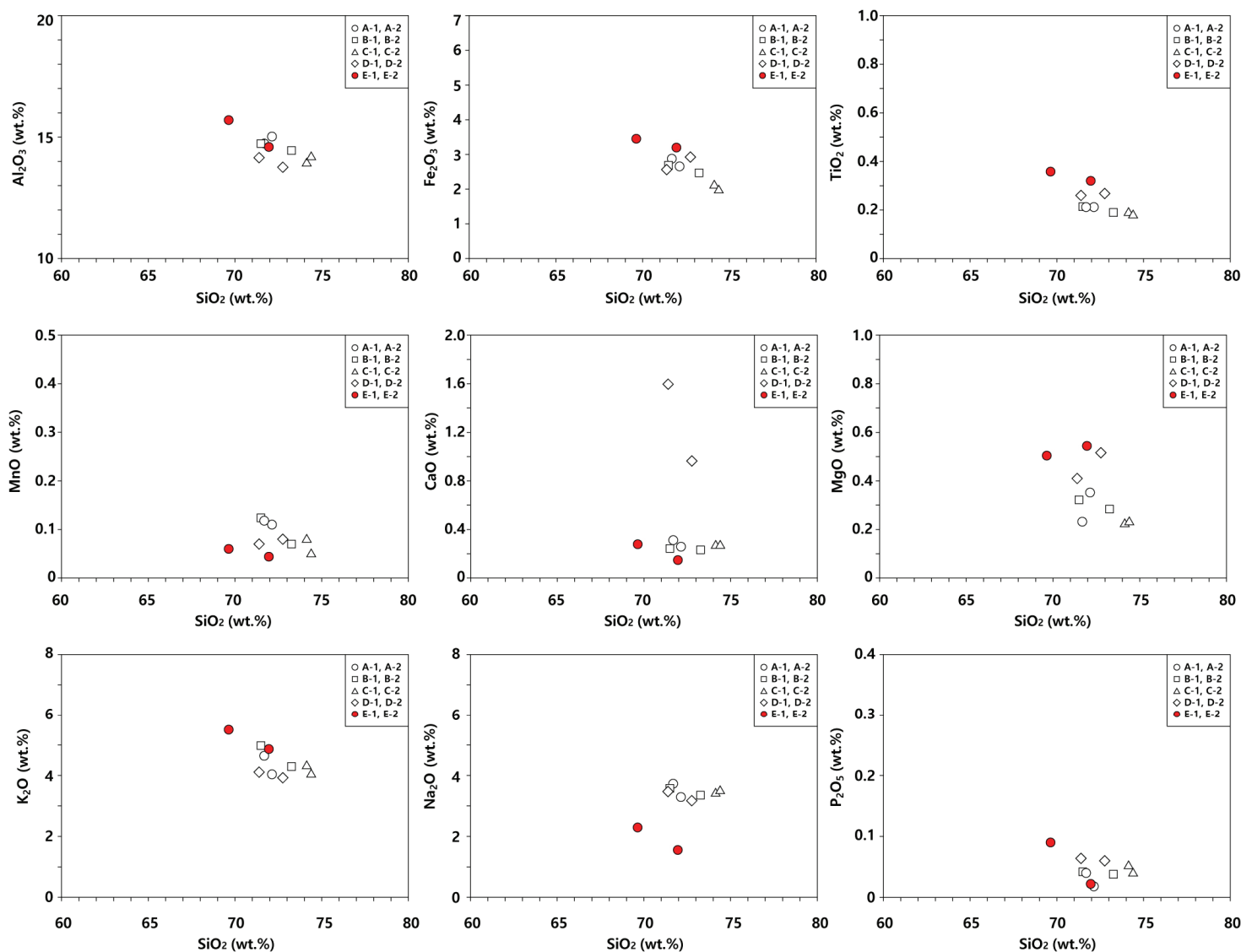

Figure 8. Harker variation diagrams for the lapilli tuff and the rhyolitic tuff samples. Samples A-1 to E-2 were obtained from the locations indicated in Figure 2.

\subsection{Physical properties}

The absorption rate of the lapilli tuff was $3.03 \sim 4.39 \%$, which was similar in all specimens, whereas the rhyolitic tuff showed large deviations of $1.89 \%$ and $5.13 \%$ in the two samples (E-1 and E-2). The apparent porosity of the lapilli tuff ranged from 7.24 to $10.14 \%$, while samples from high altitude (C-1, C-2, D-1 and D-2) exhibited higher apparent porosity values. On the other hand, samples of the rhyolitic lapilli tuff showed porosities of $4.70 \%$ and $11.70 \%$, respectively, and the deviation between the two samples was as large as that of the absorption rate. The large difference in the absorption and porosity values for the rhyolitic tuff was likely caused by differential weathering of the exposed bedrock. However, both rock types had similar apparent specific gravities of $2.32 \sim 2.60$ (Figure 9).

\section{DISCUSSION AND CONCLUSION}

The constituent rocks of Obongsan Mountain, commonly used as Gudlejang, were identified as green rhyolitic tuff, containing various types of lithic fragments. Gudlejang is a flat stone used in Ondol, where it stores heat and forms the floor of the room itself. Granite and gneiss have been used extensively as Gudlejang, and the use of slate is also common, because of its tendency to split easily. In addition, mica-bearing granite is also suitable, because granite has a relatively high thermal conductivity, and mica has low thermal conductivity, so the stones emit heat gradually (Lee, 2010).

It has been presumed that the stones used as Gudlejang were chosen based on their thermal conductivity and ease of quarrying. However, stones of the Obongsan Mountain (Quarry sites A to D), which features the largest Gudlejang 

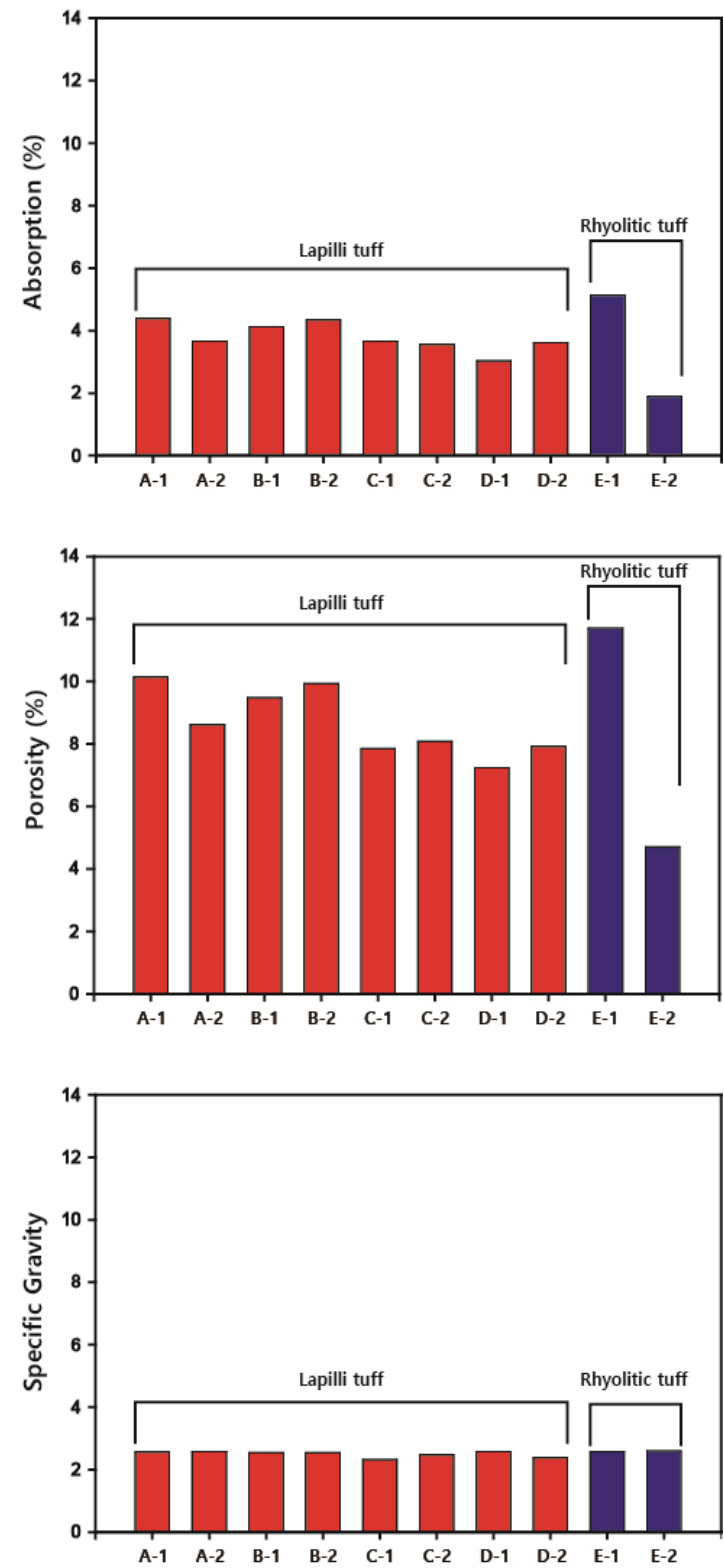

Figure 9. Physical properties of the lapilli tuff and the rhyolitic tuff. Samples A-1 to E-2 were obtained from the locations indicated in Figure 2.

quarry in Korea, consists of lapilli tuff. In general, tuff has a thermal conductivity of approximately $3.89 \mathrm{~W} / \mathrm{mK}$, which is similar to that of granite or metamorphic rocks, confirming its suitability for use as Gudlejang (Lee, 2007).

The lapilli tuff used for Gudlejang has low specific gravity, and high porosity and water absorption. In general, porosity and thermal conductivity are inversely proportional (Park et al., 2009). Although these tuff species have relatively low thermal conductivity and thermal storage properties, they have been reported to have excellent thermal durability and economic efficiency (Kim, 2009). In particular, plate-shaped joints are well developed in the lapilli tuff found at the Obongsan Mountain area, forming a talus terrain. Therefore quarrying of these stones was facilitated by the characteristics of the terrain, and it is presumed that the plate joints developed in the lapilli tuff made them easy to process for use as Gudlejang. Therefore, the Obongsan Mountain area has specific terrain and geological characteristics, resulting in rocks that are easily quarried and that work well as Gudlejang. This area is interpreted as a place where quarrying has been actively conducted.

In addition, in sites $\mathrm{A}$ and $\mathrm{B}$, many flat stones were stacked to form stone walls. However, since much of the surface of these areas is covered by recent alluvial sediments, it is presumed that these flat stones were obtained from an area further up the mountain slope. Comparing the magnetic susceptibility measurements for sample obtained at different altitudes on the Obongsan Mountain, the area above the site $\mathrm{D}^{\prime}$ exhibited a relatively high value, while site $\mathrm{C}$ low value. Therefore, it is assumed that the Gudeuljang stones stacked in site A and B were mainly quarried in near the top of the mountain (Site D and $\mathrm{D}^{\prime}$ ) and moved to the lower area.

In conclusion, the Gudlejang quarry in Obongsan Mountain has developed a talus terrain through natural causes, resulting in stone is easily quarried and naturally forms flat-shaped rocks. In addition, because it was the rocks were suitable for use as Gudlejang stones, in terms of lithology and thermal conductivity, this area became the largest quarry for Gudlejang stone.

\section{ACKNOWLEDGEMENTS}

This thesis was written based on the international academic presentation data held by the International Society of Ondol in July 2021, and I would like to thank the International Ondol Society and Boseong-gun Office for their help with the study.

\section{REFERENCES}

Cha, K.J., 2017, Spend the winter of ancestors: The best heating invented by mankind 'Ondol', Munhwajae Sa-Rang. 
Cultural Heritage Administration, 44. (in Korean)

Cultural Heritage Administration, 2005, Standard Specification for Repair of Cultural Heritage Repair, 203. (in Korean)

Hwang, I.J. and Jong, C.S., 1968, Geological report of the Boseong sheet(1:50,000). Geological Survey of Korea, 1-20. (in Korean with English abstract)

Jung, M.H., 2006, Neoteric use of traditional Korean underfloor heating system. Mater's dissertation, Chonnam National University, Gwangju, 21. (in Korean with English abstract)

Jwa, Y.J., Kim, K.K., Ko, S.B. and Kim, J.S., 2006, Source area of the rocks using the West Stone Pagoda of Gameunsaji temple site, Korea, The Petrological Society of Korea, 15(3), 128-138. (in Korean with English abstract)

Kim, J.B., 1992, A study on constructions of traditional KUDEUL in Korea. Master's dissertation, Myong Ji University, Seoul, 5. (in Korean with English abstract).

Kim, J.H. and Jwa, Y.J., 2010, A study on the provenance of the stone and the surface cracks in the Suljeongri East Three-story Stone Pagoda, Changnyeong, Korea, The Petrological Society of Korea, 19(4), 283-292. (in Korean with English abstract)

Kim, J.M., 2021, Boseong obongsan gudlejang quarry and transport route structure. The $20^{\text {th }}$ International Conference, Journal of International Society of Ondol, 121-181.
Kim, S.C., 2009, An investigation into the characteristics of Gudlejang rocks used by our ancestors, The 55th National Science Exhibition, Investigation Report, 26-50. (in Korean)

Lee, D.B., 2010, Ecological philoscophy in the Gudeul, Munhwajae Sa-Rang, Cultural Heritage Administration, (http://www.cha.go.kr/love/ebook/63/ebook.htm). (in Korean)

Lee, J.Y., Koo, H.B., and Kim, S.H., 2009, The case study of rock-slope fall by talus and coal shale, Proceedings of the Korean Geotechnical Society Conference, 1175. (in Korean with English abstract)

Lee, Y.M., 2007, Thermal conductivity of rocks for geothermal energy utilization, Proceedings of Korea Society of Geothermal Energy Engineers, 3(2), 13. (in Korean)

Park, J.M., Kim, H.C., Lee, Y.M., Shim, B.O. and Song, M.Y., 2009, Thermal properties of rock in the Republic of Korea. Economic and Environmental Geology, 42(6), 591-598. (in Korean with English abstract)

Uchida, E., Cunin, O., Suda, C., Ueno, A. and Nakagawa, T., 2007, Consideration on the construction process and the sandstone quarries during the Angkor period based on the magnetic susceptibility, Journal of Archaeological Science, 34(6), 924-935. 